\title{
Effect of the prostaglandin precursor, arachidonic acid, on histamine stimulated gastric secretion in the conscious dog, and observations on the effect of inhibiting endogenous prostaglandin synthesis
}

\author{
M. E. CONOLlY ${ }^{1}$, P. R. BIECK, N. A. PAYNE, B. ADKINS, AND J. A. OATES \\ From the Division of Clinical Pharmacology, Vanderbilt University Medical Center, Nashville, \\ Tennessee 37232, USA
}

SUMMARY The effects of intravenous infusions of prostaglandin $\mathrm{E}_{2}\left(\mathrm{PGE}_{2}\right)$ and arachidonic acid (AA) on histamine-stimulated gastric secretion have been studied in conscious dogs with either a simple gastric fistula or a denervated Heidenhain pouch. Both compounds produced a dose-related inhibition of acid secretion, though AA was 86.5 to 203.2 times less potent than $\mathrm{PGE}_{2}$. The maximal effect of AA was not achieved until 20 to 40 minutes after the infusion had ceased, suggesting that AA has to undergo some kinetic or metabolic process before it can act. Eicosatetraynoic acid (ETYN) $1.0 \mu \mathrm{g} \cdot \mathrm{kg}^{-1} \mathrm{~min}^{-1}$, an inhibitor of PG biosynthesis, almost totally abolished the anti-secretory effect of AA up to $200 \mu \mathrm{g} \cdot \mathrm{kg}^{-1} \mathrm{~min}^{-1}$. At $400 \mu \mathrm{g} \mathrm{AA} \cdot \mathrm{kg}^{-1} \mathrm{~min}^{-1}$, the antisecretory effect was reduced by about one half. The effect of $\mathrm{PGE}_{2}$ was not altered by ETYN. Furthermore, ETYN did not increase the response to histamine stimulation in control studies, which suggests that, in this model at least, prostaglandins are not involved in regulating gastric secretion.

Prostaglandins (PG) have been studied extensively as inhibitors of gastric acid secretion since the original observations of Robert et al. (1967). There is a fair degree of consistency in the reports so far published indicating that basal gastric acid secretion and secretion stimulated in several different ways is reduced or inhibited by prostaglandins in several species, including man. Thus Robert et al. (1967) showed infusions of $\mathrm{PGE}_{1}$ to abolish the secretory response to food, histamine, pentagastrin, and deoxyglucose in the dog. PGE 2 inhibited the effect of food and histamine. It has also been demonstrated that, in anaesthetised rats, large doses of $\mathrm{PGE}_{1}$ flowing through the lumen of the stomach effectively suppressed acid secretion which had been stimulated by a variety of secretagogues (Shaw and Ramwell, 1968).

By contrast, in man, oral $\mathrm{PGE}_{1}$ in tolerable doses is without effect on acid secretion (Horton et al., 1968) but Classen et al. (1970) have shown that intra-

\footnotetext{
'Present address: Department of Clinical Pharmacology, Royal Postgraduate Medical School, Du Cane Road, London W12.
}

Received for publication 4 November 1976 venous infusion of $\mathrm{PGE}_{1}$ does reduce acid output. The 15-methyl and 16.16 dimethyl analogues of $\mathrm{PGE}_{2}$, which are relatively resistant to metabolic degradation, have been found to suppress basal acid secretion in man when given by mouth (Karim et al., 1973; Robert et al., 1974).

This paper describes studies undertaken to quantify the inhibitory effect of the prostaglandin precursor, arachidonic acid (AA), on histamine stimulated secretion in conscious dogs and to compare this with the effects of $\mathrm{PGE}_{2}$. Numerous compounds are now available which inhibit the transformation of fatty acids to biologically active compounds such as PG. We have used one of these, eicosatetraynoic acid, to explore the role of such endogenous biotransformation in modulating the secretory response to histamine, and also to evaluate the importance of biotransformation of arachidonic acid to $\mathrm{PGE}_{2}$, and possibly other compounds, in producing its inhibitory effect.

\section{Methods}

The studies were carried out in trained fasted conscious mongrel dogs weighing between 10 and $22 \mathrm{~kg}$ 
in which had been fashioned either a denervated isolated (Heidenhain) gastric pouch (six dogs), or a simple gastric fistula to a stomach with intact innervation (nine dogs). Each dog was studied on several occasions and at varying doses. ${ }^{1}$

The dogs were supported by a canvas sling, and drugs were administered by an infusion pump into a peripheral vein.

The stimulus to secretion was provided by histamine given by intravenous infusion. The dose of histamine used was that which produced $50 \%$ of the maximum secretory response, as determined in a preliminary study in each dog.

Dogs with an intact vagus (gastric fistula dogs) had an extremely variable acid output during the course of a four hour study (Fig. 1a), which made the accurate assessment of the effect of inhibitors difficult to evaluate. This is in accord with previous observations indicating that the gastric response to secretory stimuli is profoundly influenced in the intact animal by many variables, notably vagal tone (Hirschowitz and Robins, 1966; Emas and Grossman, 1967; Emas, 1968; Hirschowitz, 1968). It was possible to overcome this variability by giving the dogs atropine $(0.04 \mathrm{mg} / \mathrm{kg})$ at the start of the experiment, after which, increasing the dose of histamine to twice the original dose restored $\mathrm{HCl}$ secretion to its former rate. Infusion of half the initial dose of atropine during the study $\left(0.02 \mathrm{mg} \cdot \mathrm{kg}^{-1} / 4 \mathrm{~h}\right)$ was found to maintain vagal blockade at its initial level, and using this technique a stable baseline was achieved (Fig. 1b). In contrast, acid secretion in the non-atropinised Heidenhain pouch dogs was relatively stable (Fig. 1c). In this latter group, and in the gastric fistula dogs once atropinised, there was little day-to-day fluctuation in basal acid secretion, so that there was no need to reject any studies for this reason.

Gastric juice was collected every 10 minutes in Heidenhain dogs and every 20 minutes in fistula dogs and an aliquot was titrated with $0.1 \mathrm{~N} \mathrm{NaOH}$ to pH 7.0 determined by indicator dye (bromophenol red), for determination of $\mathrm{HCl}$ content, the total $\mathrm{H}^{+}$secretion rate being thence calculated for the period of each collection.

Once the response to histamine reached its 'plateau', 80 minutes after the start of the infusion, infusion of $\mathrm{PGE}_{2}$ or AA was started. This lasted for one hour; the histamine infusion continued in parallel with, and for 90 minutes after, the end of the PG or AA infusion. In those experiments which involved eicosatetraynoic acid, this compound was infused from the 80th minute, the start of the arachidonic acid or $\mathrm{PGE}_{2}$ being delayed until the 100 th minute, from which point both drugs were infused for 60 minutes; the histamine continuing during and for 90 minutes after the infusion of these drugs as before.

\section{DRUGS}

Histamine dihydrochloride (Fisher) was dissolved in saline and infused at a predetermined rate derived as

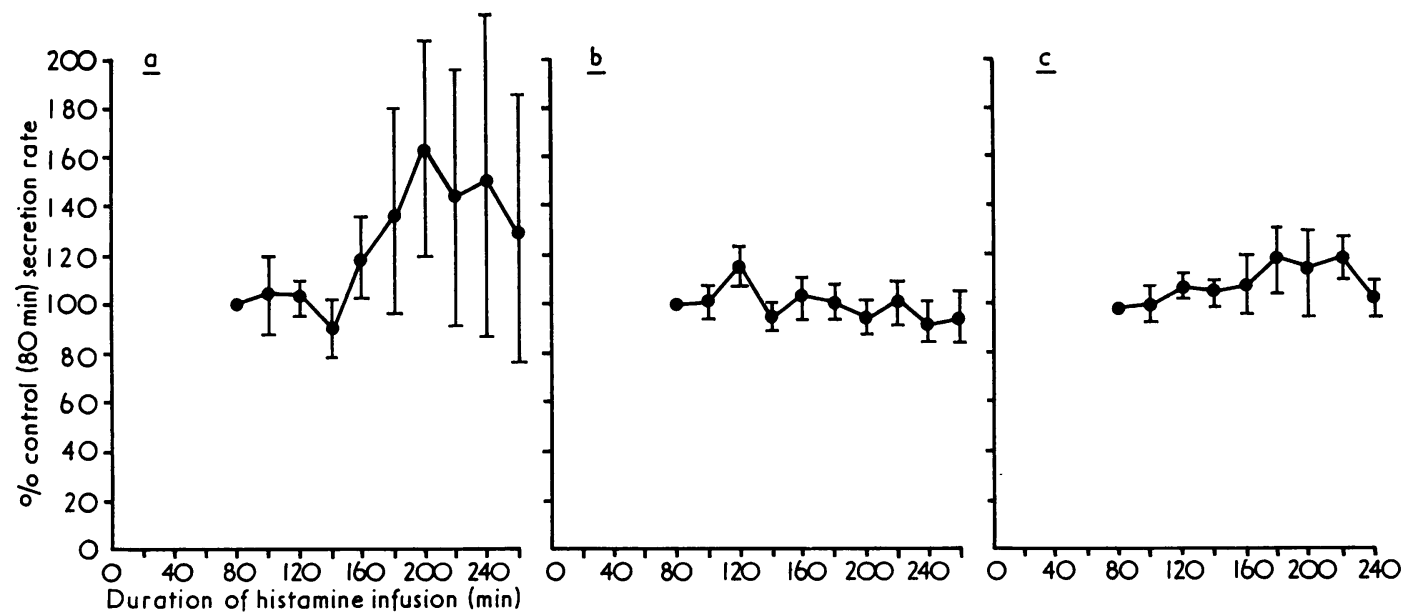

Fig. 1 (a) Acid secretion in response to half maximal dose of histamine infused for 260 minutes. Responses are expressed as mean $( \pm 2 S E$ ) percentage of the secretion rate achieved by $\varepsilon 0$ minutes. Values obtained from seven conscious, non-atropinised dogs with gastric fistulae. (b) Identical study to that shown in (a), after each animal had been atropinised. Histamine dose $2 \times E D_{50}$. (c) Acid secretion in response to half maximal dose of histamine infused for 240 minutes. Responses (mean $\pm 2 S E$ ) expressed as in (a). Values obtained in five conscious non-atropinised dogs with Heidenhain pouch. 
described above. There was considerable betweensubject variation in dose, the optimal dose, derived as described above, ranging from 30 to $73 \mu \mathrm{g} \cdot \mathrm{kg}^{-1}$ $h^{-1}$ of the salt; the range of doses required by both types of dog was similar.

\section{Prostaglandin $E_{2}$}

This was a gift from Dr J. E. Pike, Upjohn Co. ${ }^{1}$ Stock solution of $\mathrm{PGE}_{2}$ in ethanol was kept at $-20^{\circ} \mathrm{C}$ under nitrogen. It was prepared immediately before use as follows.

The required amount of stock solution was placed in a nitrogen-filled vessel. Phenolphthalein was added as indicator. The solution was then titrated with $0.01 \mathrm{~N} \mathrm{NaOH}$ using a magnetic stirrer until the first permanent red colour was achieved $(\mathrm{pH} \pm 8 \cdot 0)$. The ethanol was then evaporated in the stream of nitrogen and, just before the point of complete dryness, the resultant soap was dissolved in saline at $40^{\circ} \mathrm{C}$, using the stirrer to ensure complete solution, the volume being half the final desired volume for infusion.

Finally, canine albumin $(2 \mathrm{~g} / \mathrm{dl})$ or serum from the animal being studied (diluted with an equal volume of saline) was added. This final step complexed the PG to protein in a manner comparable with that required in preparing the arachidonate solution. It was then immediately sealed under $\mathrm{N}_{2}$ (parafilm) and transferred to the infusion pump. Doses of 0.3 to $10 \mu \mathrm{g} . \mathrm{kg}^{-1} \mathrm{~min}^{-1}$ were infused for a period of one hour. Only the very highest doses pro-

'Upjohn Co., Kalamazoo, Michigan 49001.

${ }^{2}$ Nu-Chek Prep Inc., P.O. Box 172, Elysian, Minn, 56028.

${ }^{3}$ Hoffman La Roche Inc., Nutley, New Jersey 07110.

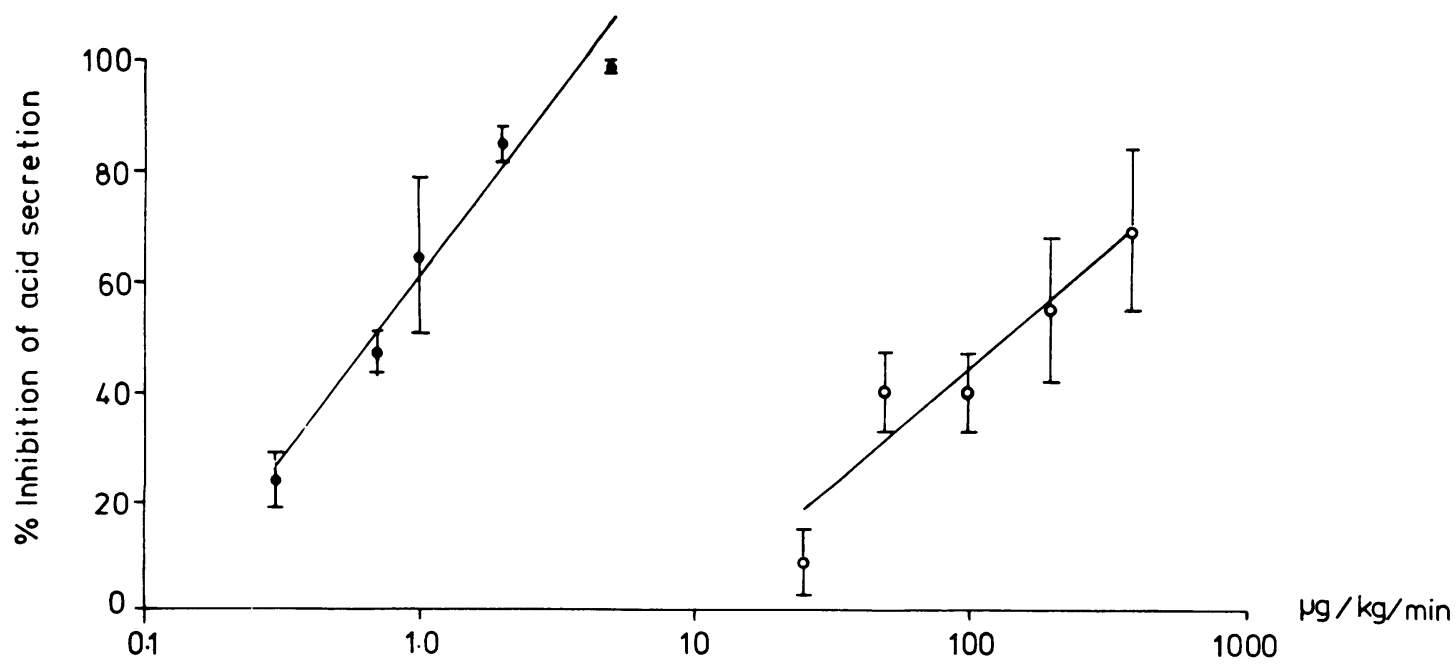

Fig. 2 Maximal inhibition of the secretory response to histamine produced by a 60 minute infusion of $P G E_{2}(O)$ and $A A(O)$ in seven conscious atropinised gastric fistula dogs. Doses of antagonists infused are plotted in $\mu \mathrm{g} . \mathrm{kg}^{-1} \mathrm{~min}^{-1}$.

\section{Arachidonic acid}

This was purchased from Nu-Chek Prep Inc. ${ }^{2}$ The sealed ampoules were kept at $-20^{\circ} \mathrm{C}$ until needed. Extreme care was needed to prevent spontaneous conversion of arachidonic acid to $\mathrm{PGE}_{2}$ or other biologically active lipids (Splawinski et al., 1973), so that, when the ampoules were opened, the contents were immediately transferred to a vial under a stream of nitrogen and then dissolved in ethanol, after which they were titrated as above, except that, because of the larger quantities involved, $1.0 \mathrm{~N}$ $\mathrm{NaOH}$ was used. After titration, the solution was extremely carefully evaporated under nitrogen, since it was found that sponteneous degradation was most likely to occur at this stage, if the soap were allowed to dry out completely. Therefore, just before the soap solution reached dryness it was taken up in saline, and the protein added as described above. The resultant solution should be optically clear (or at least no more cloudy than the serum if that was the source of the protein). It was found by experience that solutions which became cloudy on addition of protein were unsatisfactory and, as it proved impossible to redissolve the fatty acid once this happened (warming, sonification), all such solutions were discarded. Doses of $10-400 \mu \mathrm{g} . \mathrm{kg}^{-1} \mathrm{~min}^{-1}$ (the maximum the dogs could tolerate in a peripheral vein because of local irritation) were infused for a period of one hour.

\section{Eicosatetraynoic acid}

This was kindly supplied by Dr E. Whitman. ${ }^{3}$ The 
precautions described above were used to prepare the dose solutions of this unsaturated fatty acid.

This compound was used as an inhibitor of PG synthesis in a dose of $1.0 \mu \mathrm{g} . \mathrm{kg}^{-1} \mathrm{~min}^{-1}$ for 20 minutes before, and during the whole 60 minutes of the arachidonic acid or PG infusion.

ANALYSIS OF ACID SECRETION DATA

For purposes of statistical analysis, the responses were expressed as percent inhibition of the maximal (or 'plateau') secretion rate achieved before the infusion of $\mathrm{PGE}_{2}$ or arachidonic acid was begun. The percent inhibition achieved by each dose was plotted against the dose as a conventional log dose-response curve (Figs. 2 and 3). Where the effect of eicosatetraynoic acid was being examined, the maximum inhibition achieved by the doses of $\mathrm{PGE}_{2}$ or arachidonic acid in the presence or absence of eicosatetraynoic acid (in the same animal) were plotted in like manner (Fig. 7). In both sets of experiments these 'curves' were then examined for coincidence and parallelism, using the methods described elsewhere (Conolly et al., 1971).

\section{Results}

\section{PROSTAGLANDIN INFUSION}

$\mathrm{PGE}_{2}$ in doses of 0.3 to $5.0 \mu \mathrm{g} . \mathrm{kg}^{-1} \mathrm{~min}^{-1}$ in dogs with a gastric fistula and in doses ranging from 1.0 to $10.0 \mu \mathrm{g} \cdot \mathrm{kg}^{-1} \mathrm{~min}^{-1}$ in dogs with a Heidenhain pouch produced a dose related inhibition of secretion (Tables 1 and 2). The dose-response curves were parallel but that relating to the Heidenhain pouch dogs was significantly to the right of the fistula dog
Table 1 Inhibition of histamine induced acid secretion in atropinised gastric fistula dog by IV PGE

\begin{tabular}{llcl}
\hline Dog no. & $\begin{array}{l}P G E_{2} \\
\mu g \cdot \mathrm{kg}^{-1} \text { min }^{-1}\end{array}$ & $\begin{array}{l}\% \text { inhibition } \\
\text { of secretion }\end{array}$ & Mean $\pm S E$ \\
\hline 38 & $0 \cdot 3$ & 19 & $24 \cdot 0 \pm 5 \cdot 0$ \\
40 & $0 \cdot 3$ & 29 & \\
38 & $0 \cdot 7$ & 51 & $47 \cdot 5 \pm 3 \cdot 5$ \\
40 & $0 \cdot 7$ & 44 & \\
54 & 1 & 81 & \\
53 & 1 & 22 & \\
58 & 1 & 82 & \\
24 & 1 & 43 & \\
38 & 1 & 95 & \\
38 & 2 & 87 & \\
40 & 2 & 77 & \\
71 & 2 & 78 & \\
24 & 2 & 87 & \\
38 & 2 & 95 & \\
38 & 5 & 100 & \\
58 & 5 & 99 & \\
\hline
\end{tabular}

Table 2 Inhibition of histamine induced acid secretion in Heidenhain pouch dogs by IV PGE

\begin{tabular}{lcll}
\hline Dog no. & $\begin{array}{l}P G E_{2} \\
\mu g \cdot \mathrm{kg}^{-1} \min ^{-1}\end{array}$ & $\begin{array}{l}\% \text { inhibition } \\
\text { of secretion }\end{array}$ & Mean $\pm S E$ \\
\hline 37 & 1 & 35 & \\
59 & 1 & 15 & $26 \cdot 3 \pm 5 \cdot 9$ \\
61 & 1 & 29 & \\
61 & 2 & 39 & $39 \cdot 7 \pm 0 \cdot 7$ \\
59 & 2 & 41 & \\
61 & 2 & 39 & \\
62 & 5 & 80 & \\
63 & 5 & 98 & \\
37 & 10 & 97 & \\
59 & 10 & 98 & 08.0 \\
61 & 10 & 96 & \\
\hline
\end{tabular}

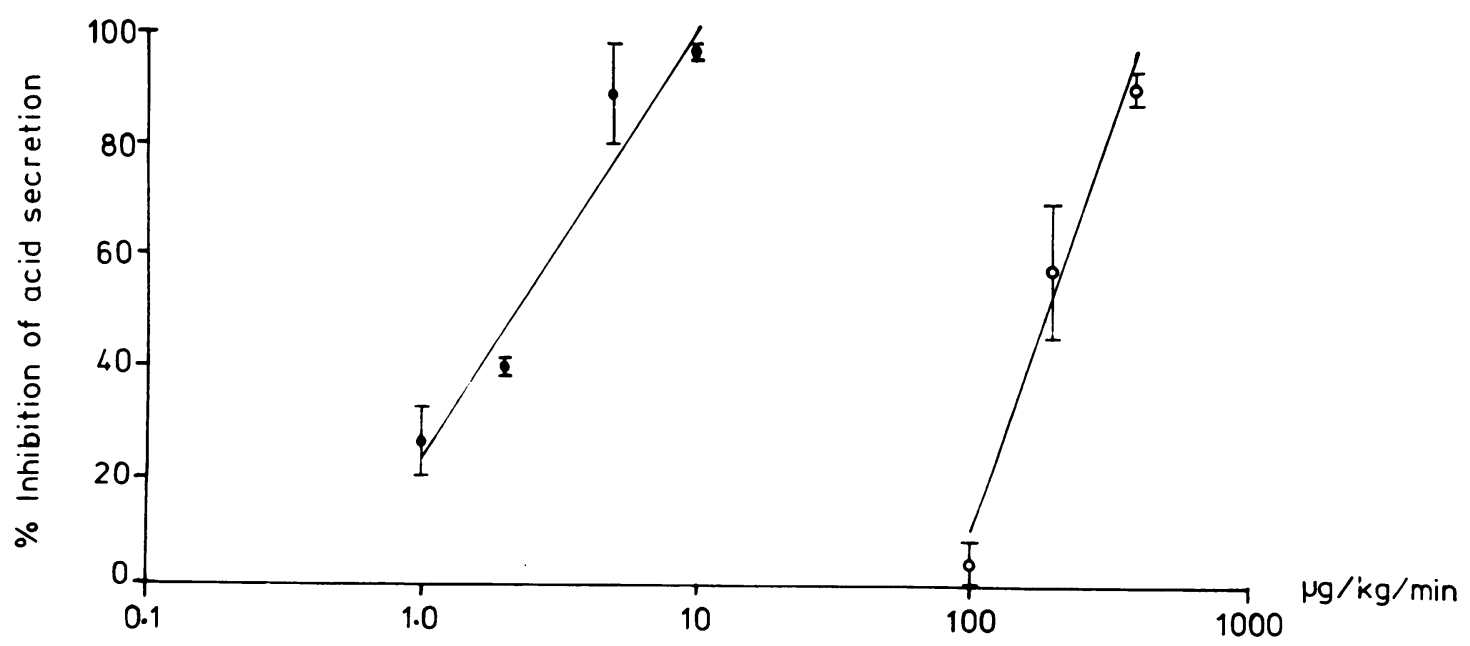

Fig. 3 Maximal inhibition of the secretory response to histamine produced by a 60 minute infusion of $P G E_{2}(\bullet)$ and $A A(O)$ in five conscious non-atropinised dogs with Heidenhain pouch. 
curve (Figs. 2 and 3); the sensitivity of the fistula dogs to the inhibitory effects of $\mathrm{PGE}_{2}$ as compared with that of the Heidenhain pouch dogs (expressed as a ratio of the calculated $\mathrm{ED}_{50} \mathrm{~s}$ ) was greater by a factor of $3 \cdot 4$.

\section{ARACHIDONIC ACID INFUSION}

Arachidonic acid was infused in doses ranging from 25 to $400 \mu \mathrm{g} \cdot \mathrm{kg}^{-1} \mathrm{~min}^{-1}$ in dogs with a gastric fistula,

Table 3 Inhibition of histamine induced acid secretion in atropinised gastric fistula dog by IV arachidonic acid

\begin{tabular}{llll}
\hline Dog no. & $\begin{array}{l}\text { Arachidonic } \\
\text { acid } \\
\mu g . \mathrm{kg}^{-1} \text { min }^{-1}\end{array}$ & $\begin{array}{l}\text { \% inhibition } \\
\text { of secretion }\end{array}$ & Mean $\pm S E$ \\
\hline 24 & 25 & 0 & \\
25 & 25 & 6 & $8 \cdot 7 \pm 5 \cdot 9$ \\
54 & 25 & 20 & \\
54 & 50 & 75 & \\
58 & 50 & 43 & \\
38 & 50 & 27 & $40 \cdot 3 \pm 7 \cdot 6$ \\
25 & 50 & 23 & \\
24 & 50 & 35 & \\
58 & 50 & 39 & \\
54 & 100 & 33 & \\
38 & 100 & 47 & \\
38 & 200 & 55 & \\
24 & 200 & 39 & \\
25 & 200 & 93 & \\
58 & 200 & 35 & \\
24 & 400 & 83 & \\
66 & 400 & 55 & $13 \cdot 2$ \\
\hline
\end{tabular}

and in doses ranging from 100 to $400 \mu \mathrm{g} \cdot \mathrm{kg}^{-1} \mathrm{~min}^{-1}$ in dogs with a Heidenhain pouch (lower doses had also been given to this latter group but were without effect and so are not included in the calculations). A significantly dose-related suppression of acid secretion was seen (Tables 3, 4). As with $\mathrm{PGE}_{2}$, at least in doses up to $200 \mu \mathrm{g} \cdot \mathrm{kg}^{-1} \mathrm{~min}^{-1}$, fistula dogs were more responsive than the Heidenhain pouch dogs to the inhibitory effects of the arachidonic acid. However, as shown in Figs. 2 and 3, the slope of the regression lines for arachidonic acid in Heidenhain pouch dogs is significantly steeper $(\mathrm{P}<$ 0.05 ) than in the fistula dogs and it appears that at the highest dose studied the inhibitory potency of

Table 4 Inhibition of histamine induced acid secretion in Heidenhain pouch dogs by IV arachidonic acid

\begin{tabular}{llll}
\hline Dog no. & $\begin{array}{l}\text { Arachidonic } \\
\text { acid } \\
\mu g . \mathrm{kg}^{-1} \text { min }^{-1}\end{array}$ & $\begin{array}{l}\% \text { inhibition } \\
\text { of secretion }\end{array}$ & Mean $\pm S E$ \\
\hline 59 & 100 & 0 & $4 \pm 4$ \\
61 & 100 & 8 & \\
59 & 200 & 12 & $57 \cdot 8 \pm 12 \cdot 2$ \\
62 & 200 & 64 & \\
61 & 200 & 71 & \\
61 & 200 & 84 & $90 \cdot 0 \pm 3.0$ \\
65 & 200 & 58 & \\
61 & 400 & 87 & \\
63 & 400 & 93 & \\
\hline
\end{tabular}
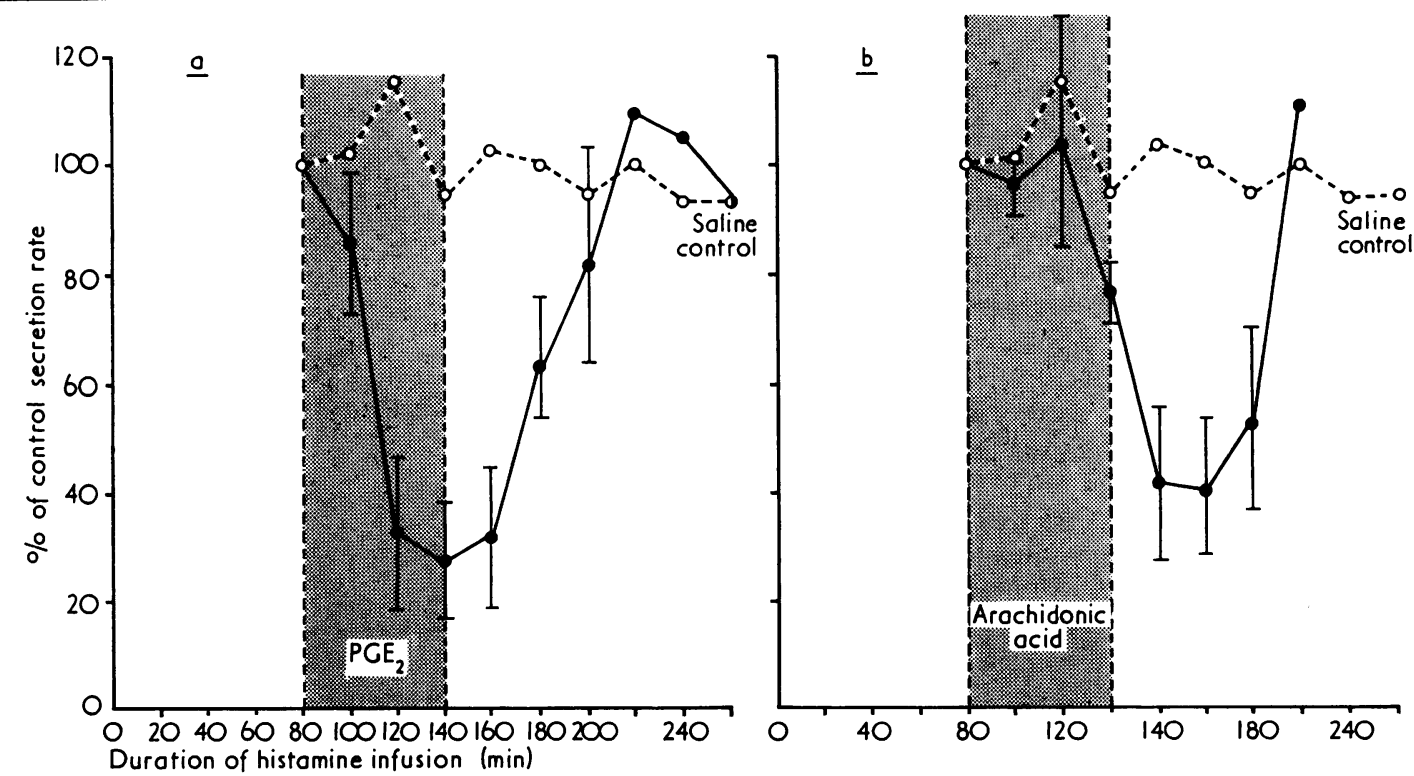

Fig. 4 (a) Time course of the inhibitory effect of $P G E_{2}\left(1 \cdot 0 \mu \mathrm{g} . \mathrm{kg}^{-1} \mathrm{~min}^{-1}\right)$ on histamine stimulated gastric acid secretion in five conscious atropinised gastric fistula dogs. Duration of infusion of $P G E_{2}$ or saline shown by shaded zone. Response to $P G E_{2}--O$, to saline $\bigcirc--\bigcirc$. Values are plotted as mean $( \pm 2 S E)$ percentage of the secretion rate achieved after 80 minutes infusion of histamine. (b) Time course of the inhibitory effect of AA $\left(200 \mu \mathrm{g} . \mathrm{kg}^{-1} \mathrm{~min}^{-1}\right)$ on histamine stimulated gastric acid secretion in four conscious atropinised gastric fistula dogs. Values expressed as in (a). Response to AA - - , to saline $\bigcirc--\bigcirc$. 

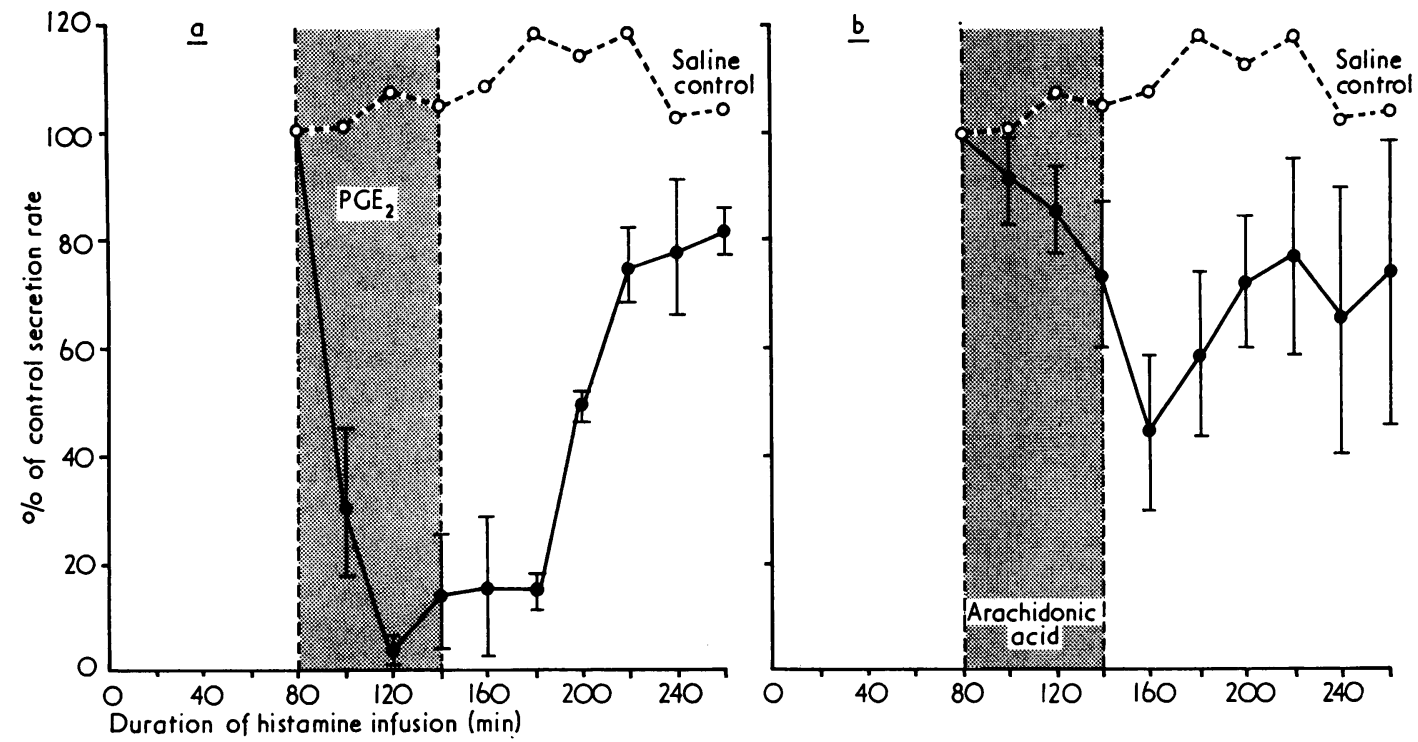

Fig. 5 (a) Time course of the inhibitory effect of $P G E_{2}\left(10 \cdot 0 \mu \mathrm{g} \mathrm{kg}^{-1} \mathrm{~min}^{-1}\right)$ on histamine-stimulated acid secretion in three conscious non-atropinised Heidenhain pouch dogs. Duration of infusion of $P G E_{2}$ and placebo shown by shaded zone. Response to $P G E_{2}-0$, to saline $\bigcirc---\bigcirc$. Values are plotted as mean $( \pm 2 S E)$ percentage of the secretion rate achieved after 80 minutes' infusion of histamine. (b) Time course of the inhibitory effect of AA $\left(200 \mu \mathrm{g} . \mathrm{kg}^{-1} \mathrm{~min}^{-1}\right)$ on histamine stimulated acid secretion in five conscious non-atropinised Heidenhain pouch dogs. Values expressed as in (a). Response to AA - - , to saline $\bigcirc---\bigcirc$.

arachidonic acid is greater in the Heidenhain pouch dogs.

\section{COMPARISON OF PGE2 AND ARACHIDONIC}

ACID

The inhibitory effects exerted by these two compounds differ qualitatively as well as quantitatively.

The time course of their effects is different (Figs. $4 \mathrm{a}$ and $4 \mathrm{~b}$ ). In the gastric fistula dogs the maximum inhibitory effects of $\mathrm{PGE}_{2}$ occurred during the infusion, whereas with arachidonic acid the maximum observed inhibition did not occur until $\mathbf{4 0}$ minutes after the infusion had ceased. In the Heidenhain pouch dogs this difference was less clear cut, but still occurred (Figs. 5a and 5b).

$\mathrm{PGE}_{2}$ proved far more effective than arachidonic acid in both types of dog. In fistula dogs, in whom the dose response curves for $\mathrm{PGE}_{1}$ and $\mathrm{AA}$ were not significantly non parallel (Fig. 2), the ratio of the $E_{50}$ S was 203.2:1 in favour of $\mathrm{PGE}_{1}$. In the Heidenhain pouch dogs, where the dose response curves deviated significantly from parallelism $(\mathbf{P}<$ 0.05 ) no such precise comparison can legitimately be made. However, as can be seen from Fig. 3, the ratio of the $\mathrm{ED}_{50}$ s is $86 \cdot 5: 1$ in favour of $\mathrm{PGE}_{1}$

EFFECT OF EICOSATETRAYNOIC ACID ON GASTRIC FISTULA DOGS

Eicosatetraynoic acid, when infused $\left(1.0 \mu \mathrm{g} . \mathrm{kg}^{-1}\right.$ $\min ^{-1}$ for 80 minutes) into four dogs receiving only histamine, was associated with a slight increase in acid secretion (Fig. 6), which was not significantly

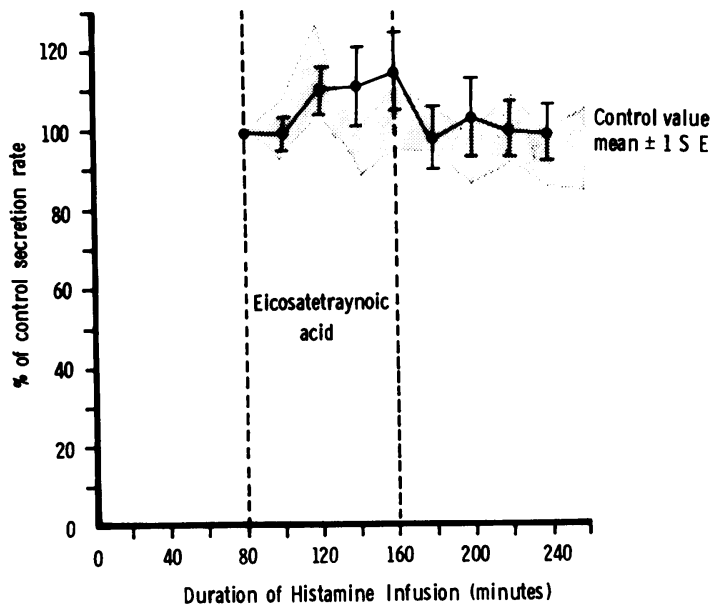

Fig. 6 Effect of infusion of eicosatetraynoic acid on response to histamine infusion in four conscious atropinised gastric fistula dogs. Eicosatetraynoic acid infused from 80-160 minutes. Response to histamine (O) plotted as mean $( \pm S E)$ percent of secretion rate achieved after 80 minutes infusion of histamine. Shaded area represents response to saline infusion from 80-160 minutes (mean $\pm 2 S E$ ) in eight animals. 
different from the control response observed in Discussion eight dogs. ${ }^{1}$

In two dogs whose gastric acid output was reduced by an infusion of $\mathrm{PGE}_{2}$, concomitant infusion of eicosatetraynoic acid produced no change in their response. However, it reduced the inhibitory effect of arachidonic acid, $200 \mu \mathrm{g} \cdot \mathrm{kg}^{-1} \mathrm{~min}^{-1}$, by $84.6 \%$ and $96.4 \%$. At the higher dose of $400 \mu \mathrm{g} . \mathrm{kg}^{-1}$ $\mathrm{min}^{-1}$, the inhibitory effect of the AA was reduced by $27.6 \%$ and $35.5 \%$ when eicosatetraynoic acid was given concomitantly (Fig. 7; Table 5).

${ }^{1}$ To achieve statistical significance with so small a difference, a minimum of 20 dogs in each group would be required.

These results amply confirm the findings of previous workers with respect to the effect of $\mathrm{PGE}_{2}$ on histamine-stimulated gastric acid secretion. For both types of dog a clearly dose-related inhibition of acid secretion is seen. Although the slopes of the dose response curves do not differ significantly, the sensitivity of the fistula dogs to the effect of $\mathrm{PGE}_{2}$ (as judged by the position of the curves) is significantly greater than that of the Heidenhain pouch dogs.

We have demonstrated that arachidonic acid also exhibits a dose dependent inhibition of histamine-

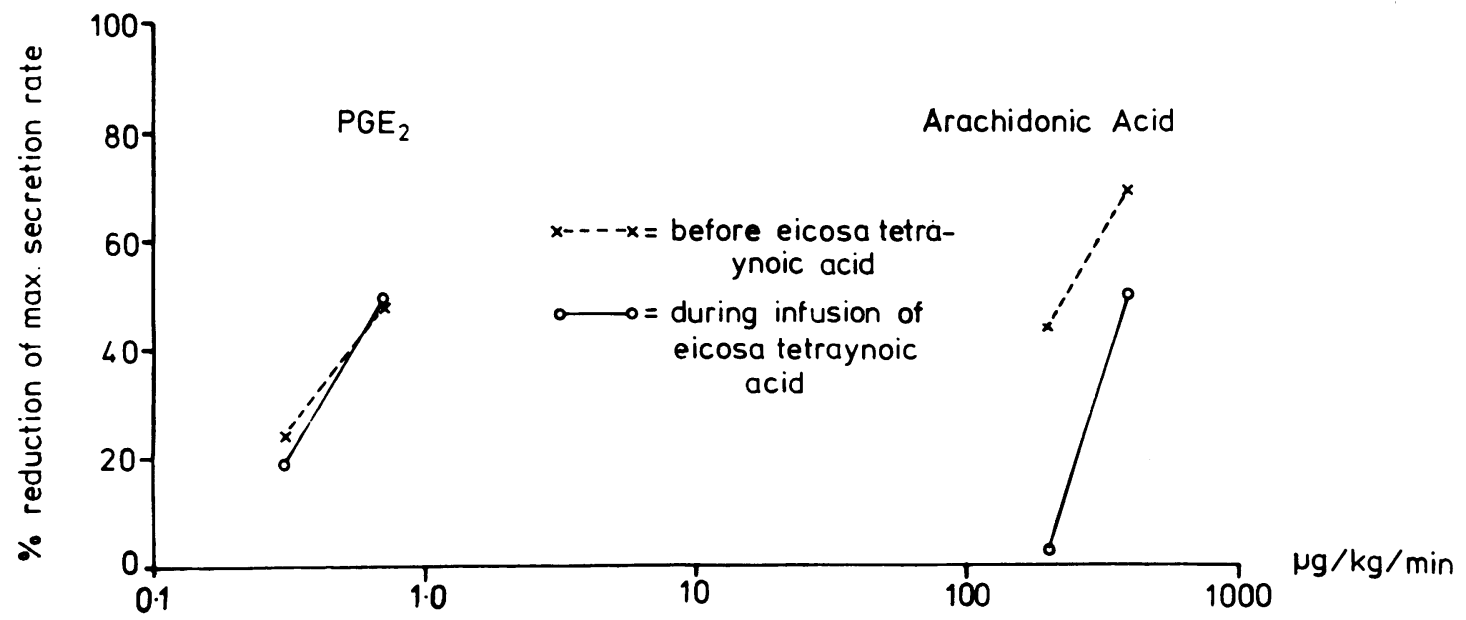

Fig. 7 The inhibitory effect of $P G E_{2}$ and $A A$ before $(x--x)$ and during $(\bigcirc-\bigcirc)$ an infusion of eicosatetraynoic acid $\left(1.0 \mu \mathrm{g} . \mathrm{kg}^{-1} \mathrm{~min}^{-1}\right)$ in conscious atropinised gastric fistula dogs. Doses of PGE and AA given as $\mu \mathrm{g} . \mathrm{kg}^{-1} \mathrm{~min}^{-1}$.

Table 5 Effect of $P G E_{2}$ and $A A$ before and during infusion of eicosatetraynoic acid

\begin{tabular}{|c|c|c|c|}
\hline \multirow[t]{2}{*}{ Dog no. } & \multirow[t]{2}{*}{ Dose of $E_{2}\left(\mu \mathrm{g} \cdot \mathrm{kg}^{-1} \mathrm{~min}^{-1}\right)$} & \multicolumn{2}{|c|}{$\%$ Suppresion of histamine-induced secretion by: } \\
\hline & & $P G E_{2}$ alone & $P G E_{2} \pm$ eicosatetraynoic acid \\
\hline $\begin{array}{l}38 \\
40 \\
38 \\
40\end{array}$ & $\begin{array}{l}0.3 \\
0.3 \\
\\
0.7 \\
0.7\end{array}$ & $\begin{array}{l}19 \\
29 \\
\text { Mean } \pm \text { SE } 24 \pm 5.0 \\
44 \\
51 \\
\text { Mean } \pm \text { SE } 48 \pm 3.5\end{array}$ & $\begin{array}{l}20 \\
17 \\
19 \pm 2 \cdot 1 \\
56 \\
44 \\
50 \pm 8 \cdot 5\end{array}$ \\
\hline \multirow[t]{2}{*}{ Dog no. } & Dose of arachidonic acid & \multicolumn{2}{|c|}{$\%$ Suppression of histamine-induced secretion by: } \\
\hline & & Arachidonic acid alone & $\begin{array}{l}\text { Arachidonic acid }+ \\
\text { eicosatetraynoic acid }\end{array}$ \\
\hline $\begin{array}{l}24 \\
38 \\
58 \\
\\
24 \\
66\end{array}$ & $\begin{array}{l}200 \\
200 \\
200 \\
\\
400 \\
400\end{array}$ & $\begin{array}{l}39 \\
55 \\
35 \\
\text { Mean } \pm \text { SE } 43.0 \pm 10 \cdot 6 \\
83 \\
55 \\
\text { Mean } \pm \text { SE } 69 \pm 14 \cdot 0\end{array}$ & $\begin{array}{l}6 \\
2 \\
2 \\
3 \cdot 3 \pm 1 \cdot 3 \\
60 \\
41 \\
50 \cdot 5 \pm 9 \cdot 5\end{array}$ \\
\hline
\end{tabular}


stimulated gastric acid secretion. In this instance, there is a significant difference in the slope of the dose response curves relating to the two types of dogs. The fistula dogs appear more responsive to low doses of arachidonic acid but less responsive to high doses than do the Heidenhain pouch dogs. There is no obvious explanation to account for this difference.

The delay in the response to arachidonic acid in doses up to $200 \mu \mathrm{g} \cdot \mathrm{kg}^{-1} \mathrm{~min}^{-1}$ (Figs. 4 and 5) suggests that it must undergo some kinetic or metabolic process before it can inhibit acid secretion. Concomitant administration of eicosatetraynoic acid which produces an irreversible inhibition of the PG synthetase system (Ahern and Downing, 1970) causes almost complete abolition of the inhibitory action of arachidonic acid in doses up to 200 $\mu \mathrm{g} \cdot \mathrm{kg}^{-1} \mathrm{~min}^{-1}$, which suggests that this action of AA depends on its enzymatic conversion either to prostaglandin(s) or an intermediate endoperoxide (Hamberg et al., 1974). The less marked inhibition of higher doses of arachidonic acid by eicosatetraynoic acid raises the possibility that part of the effect of the high dose may depend on mechanisms other than the enzymatic biotransformation of arachidonic acid (Splawinski et al., 1973).

The uptake of arachidonic acid and its partial conversion to prostaglandin (or possibly cyclic endoperoxide) suggests that it might be of value to explore the oral administration of PG precursors, as prostaglandin deprivation such as induced by aspirin-like drugs will lead to gastrointestinal ulceration in experimental animals. Furthermore, these inhibitors of PG synthesis will worsen peptic ulcer disease in man and may be associated with other intestinal lesions (Sturges and Krone, 1973). It is therefore of interest to determine whether oral administration of arachidonic acid or dihomo- $\gamma$ linolenic acid would have the opposite effect and provide a treatment for conditions such as peptic ulcer, as, although various PG analogues have been shown to be orally active, satisfactory formulation to permit their use in the clinical setting has not yet been achieved.

The inhibition of acid secretion by pharmacological doses of the PGs and the PG precursor arachidonic acid raises the possibility that PGs formed endogenously might participate in a physiological feedback regulation of acid secretion. However, it is known that in man aspirin produces no increase in gastric acid secretion (Child et al., 1976) when given in doses large enough to inhibit prostaglandin synthesis (Hamberg, 1972). Similar observations have been made in rats treated with indomethacin (Lee et al., 1971). The observation (Fig. 6) that eicosatetraynoic acid (given in a dose high enough to abolish the inhibitory effect of 200 $\mu \mathrm{g} \mathrm{AA} \cdot \mathrm{kg}^{-1} \mathrm{~min}^{-1}$ ) does not significantly increase the secretory response to an infusion of histamine, also argues against any substantial negative feedback effect dependent on endogenous PG formation.

\section{References}

Ahern, D. G., and Downing, D. T. (1970). Inhibition of prostaglandin biosynthesis by eicosa $5,8,11,14$ tetraynoic acid. Biochimica et Biophysica Acta, 210, 456-461.

Child, C., Jubiz, W., and Moore, J. G. (1976). Effects of aspirin on gastric prostaglandin E (PGE) and acid output in normal subjects. Gut, 17, 54-57.

Classen, M., Koch, H., Deyhle, P., Weidenhiller, S., and Demling, L. (1970). Wirkung von Prostaglandin $E_{1}$ auf die basale Magensekretion des Menschen. Klinische Wochenschrift, 48, 876-878.

Conolly, M. E., Davies, D. S., Dollery, C. T., and George, C. F. (1971). Resistance to beta adrenoceptor stimulants (a possible explanation for the rise in asthma deaths). British Journal of Pharmacology, 43, 389-402.

Emas, S. (1968). Vagal influences on the regulation of gastric secretion. In The Physiology of Gastric Secretion, pp. 230239. Edited by L. S. Semb, and J. Myren. Willia:1s and Wilkins: Baltimore.

Emas, S., and Grossman, M. I. (1967). Effect of truncal vagotomy on acid and pepsin responses to histamine and gastrin in dogs. American Journal of Physiology, 212, 10071012.

Hamberg, M. (1972). Inhibition of prostaglandin synthesis in man. Biochemical and Biophysical Research Communications, 49, 720-726.

Hamberg, M., Svensson, J., and Samuelsson, B. (1974). Prostaglandin endoperoxides. A new concept concerning the mode of action and release of prostaglandins. Proceedings of the National Academy of Sciences, 71, 3824-3828.

Hirschowitz, B. I. (1968). Role of $\mathrm{K}^{+}$in inhibition of gastric secretion. In The Physiology of Gastric Secretion. pp. 368371. Edited by L. S. Semb and J. Myren. Williams and Wilkins: Baltimore.

Hirschowitz, B. I., and Robbins, R. C. (1966). Direct inhibition of gastric electrolyte secretion by insulin, independent of hypoglycemia or the vagus. American Journal of Digestive Diseases, 11, 199-212.

Horton, E. W., Main, I. H. M., Thompson, C. J., and Wright, P. M. (1968). Effect of orally administered prostaglandin $E_{1}$ on gastric secretion and gastrointestinal motility in man. Gut, 9, 655-658.

Karim, S. M. M., Carter, D. C., Bhana, D., and Adaikan Ganesan, P. (1973). Effect of orally administered prostaglandin $E_{2}$ and its 15-methyl analogues on gastric secretion. British Medical Journal, 1, 143-146.

Lee, Y. H., Mollison, K. W., and Cheng, W. D. (1971). Effects of anti-ulcer agents on indomethacin-induced gastric ulceration in the rat. Archives Internationales de Pharmacodynamie et de Thérapie, 192, 370-377.

Robert, A., Nezamis, J. E., and Phillips, J. P. (1967). Inhibition of gastric secretion by prostaglandins. American Journal of Digestive Diseases, 12, 1073-1076.

Robert, A., Mylander, B., and Andersson, S. (1974). Marked inhibition of gastric secretion by two prostaglandin analogs given orally to man. Life Sciences, 14, 533-538.

Shaw, J. E., and Ramwell, P. W. (1968). Inhibition of gastric secretion in rats by prostaglandin $\mathrm{E}_{1}$. In Prostaglandin Symposium of the Worcester Foundation for Experimental Biology, 1967, pp. 55-64. Edited by P. W. Ramwell, and J. E. Shaw. Interscience Publishers: New York. 
Splawinski, J., Nies, A. S., Sweetman, B., and Oates, J. A. Sturges, H. F., and Krone, C. L. (1973). Ulceration and stric(1973). The effect of arachidonic acid, prostaglandin $E_{2}$ ture of the jejunum in a patient on long-term Indomethacin and prostaglandin $\mathrm{F}_{2} a$ on the longitudinal stomach strip of the rat. Journal of Pharmacology and Experimental Therapeutics, 187, 501-510. therapy. American Journal of Gastroenterology, 59, 162169. 